\title{
SUZIE NO FRIENDS
}

\section{Hayley Walmsley}

At I I, I read The Old Man and the Sea, a Hemmingway classic that I devoured in a single afternoon - before turning back to start it again. At 22, it was Steinbeck's Of Mice and Men. Steinbeck and Hemmingway are master storytellers, using allegory to weave seemingly simple tales that delve into the indominable spirit of man, and the lonely and dispossessed nature of those who have been marginalised. Their voices reminded me of the way my grandmother spoke; of growing up in the country; watching those around me struggle to make ends meet; and constantly moving forward, despite exceedingly difficult circumstances. Stories are the background from which I have come to know my world, and my place within it. At the age of $28 \mathrm{I}$ decided that if I was to be poor (something I considered distasteful, but for the life of me could not figure out how to remedy), I would at least do work that would make me happy.

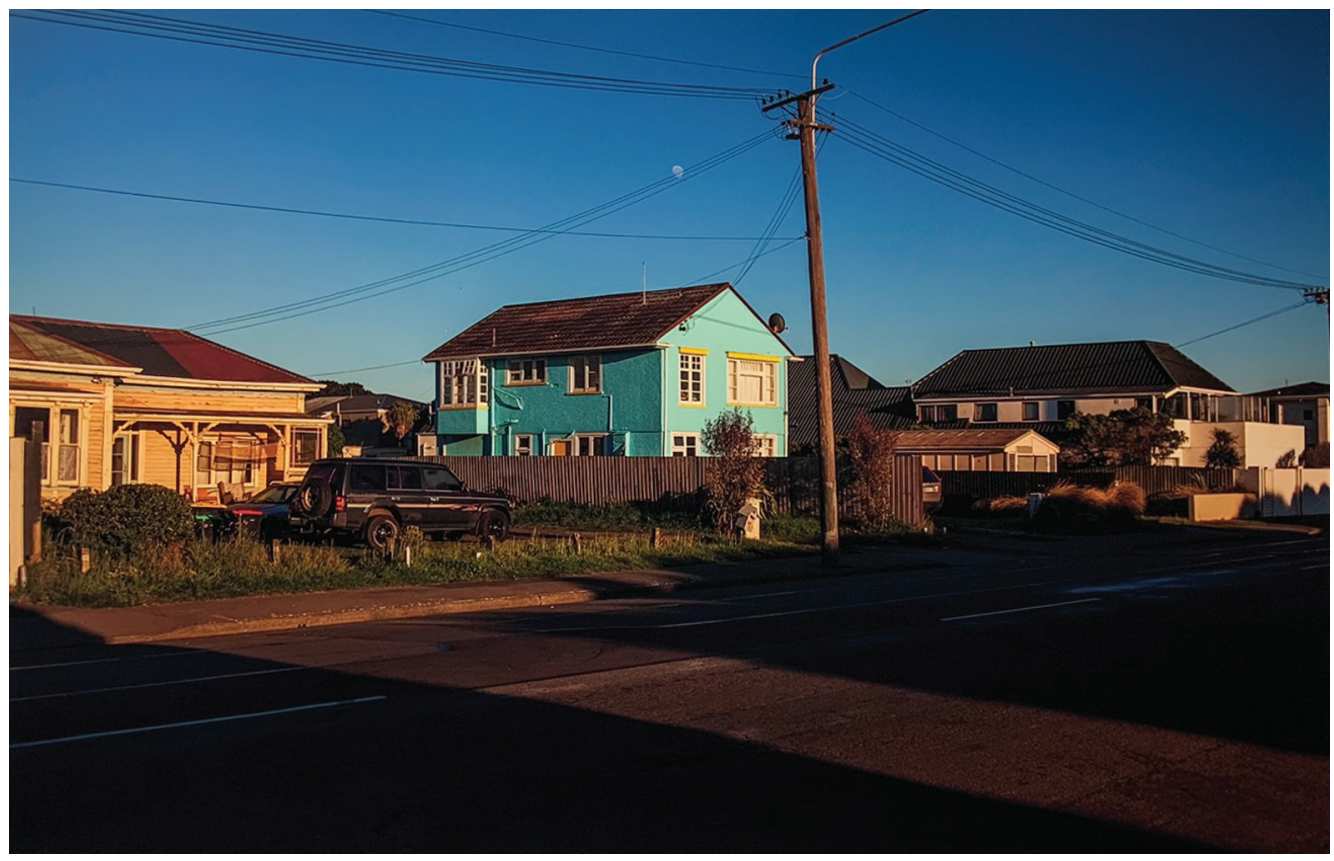

Figure I. Hayley Walmsley,

Suzie No Friends,

2019 ,

$6 \times 11$ inch inkjet print. 
And so I became an artist, trading in other people's written works for the act of creating and telling my own stories. "Suzie No Friends" (2019) developed from working in an often autobiographical practice that, however, does not focus on the autobiographical element. It is autobiographical in that each photograph adopts the tone of a "diaristic note" - documenting where l've been, what l've seen and what piqued my curiosity.' It speaks to my worries and concerns, and what keeps me up for many hours at night. Beyond that, it is not about me, as it is not directly about my own life. Contrary to the claim that my work isn't autobiographical, I find that the single best way to understand my work is to understand me.

And so, the story to be told starts in 1983 at St Helens - ironically, an Auckland hospital that no longer exists. I became the eldest daughter for my young mother, who has always done her best to provide for myself and my three younger brothers, working up to three part-time jobs and barely getting by. My mother has told me it was not uncommon for her to have only six dollars left for food after paying the bills and rent; and while six dollars went a lot further in those days, my mother didn't eat, often skipping meals to make sure we had enough.

New Zealand had faced sweeping changes in the 1970s and 80s as a result of "Rogernomics;" as a child of the 80s, these effects are still evident today. The fragmented and marginalised continue to struggle with unemployment and poverty. When freezing and meat works closed, it effected people like my mother, the working class, and Māori populations living rurally - much like the closing of factories in the cities did for people of mainly Māori and Pacifica descent who, for the most part, were already displaced from their ancestral lands.

When I was six, my mother and her boyfriend moved the family from Auckland to Kerikeri. Kerikeri is close to where my extended family are from at Matauri Bay. During that first year we lived in a packing shed with two bedrooms and a bathroom; my room was situated in the corner of the kitchen and dining area. Until this time, I had not realised we were poor. In Auckland we had lived in a state house, on a street of state houses, in a neighbourhood that at that time was a poor South Auckland suburb. It is now considered very upmarket and part of central Auckland, the by-product of gentrification. But poor 1980s Onehunga was my normal; never having seen anything of excess, I had nothing to compare it to.

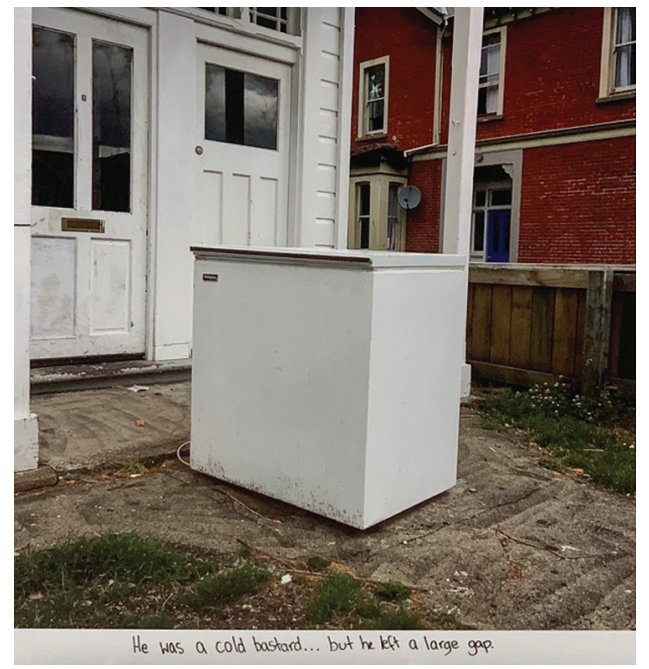

Figure 2. Hayley Walmsley,

He was a cold bastard ... but he left a large gap, 2019 ,

$44 \times 44$ inch inkjet print.

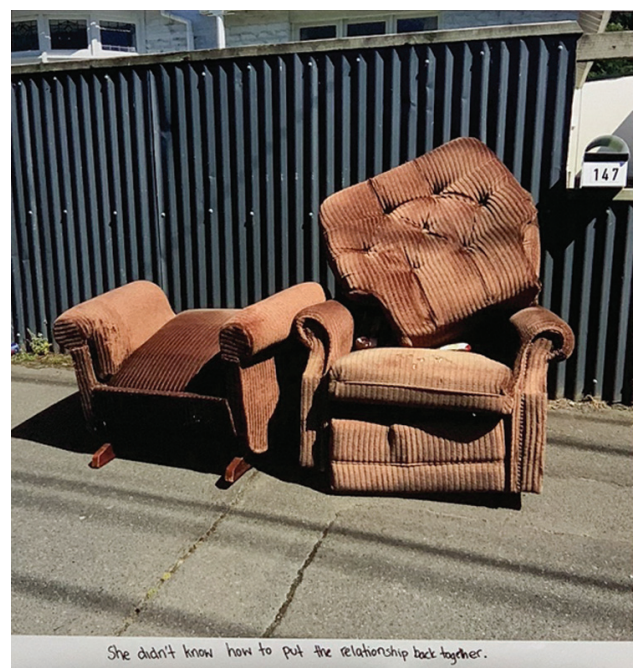

Figure 3. Hayley Walmsley,

She didn't know how to put the relationship back together, 2019 ,

$44 \times 44$ inch inkjet print. 


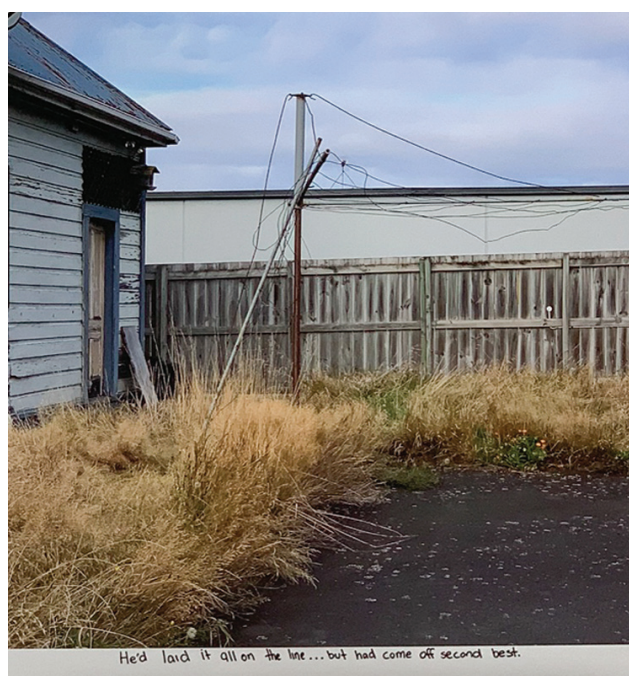

Figure 4. Hayley Walmsley,

He'd laid it all on the line ... but had come off second best, 2019 ,

$44 \times 44$ inch inkjet print.

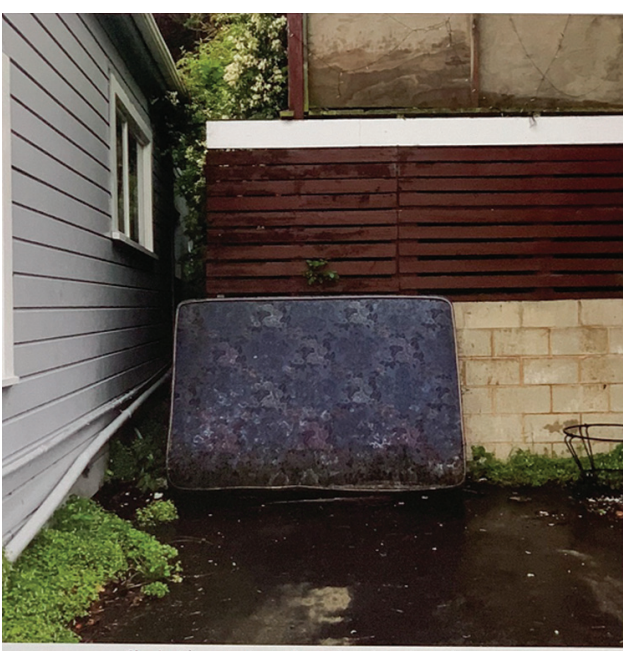

She had been in the snit so long it was changing hers.

Figure 5. Hayley Walmsley,

She had been in the shit so long it was changing her, 2019 ,

$44 \times 44$ inch inkjet print.

Growing up poor has given me an appreciation for objects and buildings that are usually functional but old, and I romanticise them. When I come across a house that is rundown, for example, I cannot help but think what it would be like to live there, as it reminds me of what it was like to stay with my grandmother in various family shacks on holiday. This appreciation has led to the creation of an ever-expanding archive. This archive is a living, breathing thing and has become a way for me to document the ephemeral - those things that may be gone tomorrow or at some indeterminate time, but will inevitably disappear. These things and places are seemingly forgotten, abandoned or neglected, and interest me as someone who often feels overlooked or isolated myself; never quite being the smartest in the room, being far away from my family, and feeling as though I haven't gotten any further than my mother has, despite the additional education I have accumulated.

Coming from a working-class family in rural Northland has highlighted both the struggles and excess in my community, as some extended family lived in shacks on family land, while some friends lived in large, spacious homes. Troubles in my own home led to arguments and, by the time I was 18 , I was ready to leave, often escaping to my grandmother's place to be near the quiet roar of the sea. Thinking myself smarter than my parents, I rushed into the big wide world - like many children who leave home at around 18 to move in with friends, start tertiary study, or because they find a job and need to move closer to work. The transitional period that happens after high school seems to be extending into longer periods away from home, as well as over further distances. Again, I mention this little bit of contextual background as a small explanation of who I am, where I come from, and how I see the world - this explains why I might be interested in the things that make my work so interesting and important to me.

Every day, no matter where I happen to be, I walk, often happening upon something interesting to photograph, never going out of my way. I firmly believe that we ascribe meaning to situations, events and objects for ourselves, and that this meaning can be different for various people. As such, I choose my subjects primarily for my interest in them visually, and only ascribe their meaning later when giving them a caption or title. The objects I come across are usually discarded and forgotten household furniture and appliances. 
Walking in Dunedin's student area in January of any given year, one will come across furniture and rubbish everywhere - left by the students who could not take it with them, or by the landlords who don't want it. Reminiscent of the work of Gabriel Orozco or Richard Wentworth, some of this detritus can be found stacked in odd formations, while other items stand alone. ${ }^{2}$ Further afield, one finds similar situations in South Dunedin, an area of condensed housing for the working class, and in Christchurch, which is still full of ruin and urban decay ten plus years post-quake. Places like Waimate, Oamaru, Alma and Palmerston lose their young each year to nearby cities, where they hope to gain an education or employment, leaving our rural towns (at least in part) in quiet decay, losing more people than they gain.

A fear of mortality can attach itself to objects devoted to the living; every photograph then becomes about death, no matter how seemingly innocuous the image is. ${ }^{3}$ Like Larry Sultan and his fear of losing his parents, my greatest fear is that once I die, I won't be

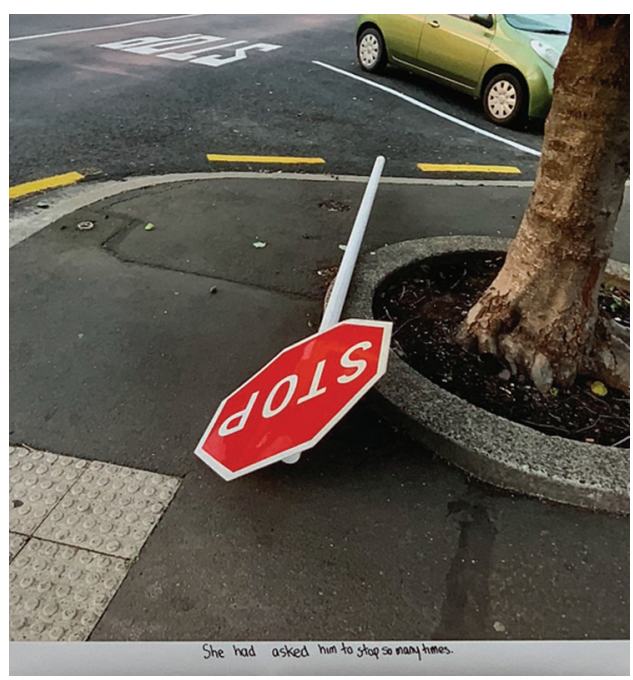

Figure 6. Hayley Walmsley,

She had asked him to stop so many times,

2019 ,

$44 \times 44$ inch inkjet print. remembered at all. Mirroring Sultan, I set up a cyclical process in which by trying to create something worth being remembered for, I am dooming myself to a certain kind of death, acknowledging that I will not be around forever - whether by choice, death or something in between. ${ }^{4}$ This gives a palpable sense of loss, even to the imperfect.

Ruins are considered the perfect allegorical vehicle, and I believe that this can be extended to urban decay and discarded objects. I rely on allegory to show people my own ascribed meanings for the objects I have photographed. These things and ideas act as an allegorical representation, standing in for humans and their societal issues. ${ }^{5}$ Speaking to a sense of loss and longing, and a seemingly hardwired need to be recognised, needed and remembered, each image is searching for a way to say a final farewell, or "look at me" - affirming that the things depicted exist, that they served their purpose, and that they played their part. Enacting a similar fear, but in a different manner to that of Bernd and Hilla Becher, I explore a world that is disappearing, yet avoid the clinical exactness of a scientific method. ${ }^{6}$

Contextual clues within these photographs are pared back, making the addition of captions or titles of substantial importance to enable me to tell stories. Cementing again the idea that we, the makers, acribe our own meanings, allegory works only because of this ascribed meaning. Allegory itself occurs when one text is doubled over another - in this case, the captions and titles provide the doubling up (or contradiction) to the images themselves. What makes these captions and titles interesting is that they are a midpoint - something has happened before, and something will happen after. But we are only given access to what is going on in this specific moment.

Each work functions on several levels - as documentary, commentary and a conversation between me, the images and the audience. If each of these things were an extension of the owner, they would be a portrait, standing in for the owner.The arduous process of sorting, resorting and handling these images over months and years has resulted in them becoming known to me like favourite people; these images are friends. Considered as the people I have given them to portray, handling them so heavily places a small piece of me with each one - much like relationships with family members and friends that influence a person. 
As I round the corner into my late thirties, living at the opposite end of the country to my home, and having returned to study (which I have now finished), the transitory nature of a migratory population has become all the more apparent to me. So too has the idea that I may never be able to return home. House prices in Kerikeri and surrounding areas are now prohibitive, and there is a lack of jobs in my chosen field. I continue to look for the next thing that will allow me to make more money, and anticipate moving further afield in the hope of one day being able to afford to go home. I am one of those who has left a small town to languish or move on without me. In a perpetuating cycle, I expect that my son may think of moving from Dunedin for the same reasons I initially left my home.

I use ruin, decay and abandoned objects as allegories to represent people and the societal issues of poverty, unemployment, isolation, domestic violence, suicide, a lack of infrastructure - and the pervasive effect this has on communities and individuals over time, representing the destruction and re-destruction of ourselves, continuously. "Suzie No Friends" examines themes of presence, absence, and loss and longing to make sense of a seemingly hardwired need to be recognised, needed and remembered; giving the neglected, the abandoned, the fragmentary, the marginal and the forgotten a platform to speak up when they often cannot do so for themselves. Much like Hemmingway and Steinbeck, these are stories I consider to be worth telling; not least because they belong to us - those often disillusioned and marginalised people, just looking for a way to belong, be remembered and eventually find our way home.

Hayley Walmsley is an artist and photographer living in Dunedin, New Zealand. She recently completed her Master of Visual Arts at the Dunedin School of Art. An absurdist by nature, she infuses humour into her work as a way of both lightening the intensity of difficult subjects and representing life as a nuanced spectrum from melancholic to wistful, whimsical and everything in between.

I Francesco Zanot, David Heath: Dialogues with Solitudes (Gottingen: Steidl/Le Bal, 20 I 8). I use the term "diaristic note" in the same sense as Heath.

2 Phyllis D Rosenzweig et al., Gabriel Orozco: Photographs (Washington, DC: Hirshhorn Museum and Sculpture Garden, Smithsonian Institution, 2004); Richard Wentworth and Hans Ulrich-Obrist, Making Do and Getting By (London: Koenig Books, 20I5).

3 Roland Barthes, Camera Lucida (London: Jonathan Cape, 1982).

4 Larry Sultan, Pictures From Home (New York: Harry N Abrams, 1992).

5 Craig Owens, "The Allegorical Impulse: Towards a Theory of Post-modernism: Part I," October, 12 (Spring 1980), 67-86. Owens refers to Walter Benjamin's idea of the ruin as the perfect allegorical vehicle because allegory is in the realm of thought what ruins are in the realm of things. Ruins are forsaken things, no longer fulfilling their original intended purpose. Quoting Benjamin quoting Marx, Owen also refers to the "object as a commodity," noting that "once the commodity has left the maker it is freed from its particularity - ceasing to be a product controlled by humans and takes on phantom-like objectivity - leading its own life."This process is mirrored again when the object is abandoned or thrown away.

6 Sean O'Hagan, "Lost World: Bernd and Hilla Becher's Legendary Industrial Photographs," The Guardian, 3 September 20 I4, https://www.theguardian.com/artanddesign/20 /4/sep/03/bernd-and-hilla-becher-cataloguing-the-ominous-sculptural-formsof-industrial-architecture. 